\title{
FRAUD PREVENTION STRATEGY WITH A MEDICOLEGAL APPROACH IN ELECTRONIC-BASED DATA COLLECTION OF THE HEALTH SYSTEM: A SYSTEMATIC REVIEW
}

\author{
Adji Suwandono, Ari Natalia Probandari, Ratih Puspita Febrinasari
}

Faculty of Medicine, Universitas Sebelas Maret

\begin{abstract}
Background: This form of fraud in the health system was not a new thing. The impact of fraud in health services has the potential to harm the state health budget. In addition, things that cannot be avoided can reduce the quality or quality of the health service itself. Regulation was an essential in one of the efforts to prevent fraud. This was used to provide clear standards to distinguish actions that are categorized as fraud or not. This study aimed to examine and analyze fraud prevention strategies in the health system with a medicolegal approach.

Subjects and Method: This study was a systematic review conducted using PRISMA flow diagram. Online articles from 2020 to 2021 were searched from databases, including PubMed, Science Direct, Scopus, and Springer Link. The PICO was as follows. Population: Health facilities. Intervention: An electronic-based health system. Comparison: Without electronic-based health system. Outcome: Fraud. Keywords ("prevention" OR "precaution" OR "deterrence") AND ("fraud" OR "abuse" OR "violation" OR "offense" OR "breach" OR "infraction") AND ("health system" OR "health care" OR "medical management" OR "health program"). A total of 1202 articles were identified. Five articles were included in the inclusion criteria.

Results: This study showed that fraud occurred when the sanctions were weak. Fraud could be prevented by the blockchain system and imposing severe sanctions. A prevention system with advanced technology was needed to reduce the number of frauds in the health services delivery.

Conclusion: A prevention system with advanced technology is needed to reduce the number of fraud in the health services delivery.
\end{abstract}

Keywords: fraud, medicolegal, electronic health system

\section{Correspondence:}

Adji Suwandono. Faculty of Medicine, Universitas Sebelas Maret. Jl. Ir. Sutami 36A, Surakarta 57126, Central Java, Indonesia. Email: adji.suwandono@staff.uns.ac.id. Mobile: 08164270612. 